\title{
Uczenie się z własnej biografii jako egzemplifikacja biograficznego uczenia się
}

\begin{abstract}
Abstrakt
Artykuł odnosi się do wyników projektu dotyczącego badania biografii, realizowanego w latach 2008-2010, pod nazwą „Uczenie się z własnej biografii”. Uczenie się $\mathrm{z}$ własnej biografii stanowi egzemplifikację biograficznego uczenia się. Tekst prezentuje wyniki badań projektowych opisujące uczenie się z własnej biografii w perspektywie: ontologicznej, epistemologicznej, metodologicznej i metodycznej; ukazuje człowieka jako istotę biograficzną. Przedstawia proces badania/poznawania własnej biografii oraz proces poznawania (rzeczywistości) poprzez biografię. Prezentuje trzy konteksty rozumienia i doświadczania uczenia się z własnej biografii. Zawiera metodyczne odniesienia dla edukacji dorosłych.
\end{abstract}

Słowa kluczowe: uczenie się z własnej biografii, biograficzne uczenie się, badania empiryczne, andragogika, edukacja dorosłych.

\section{Learning from One's Own Biography as an Exemplification of Biographical Learning}

\begin{abstract}
This article presents the results of the biographical research project titled "Learning from One's Own Biography" conducted in the years 2008-2010. Learning from one's own biography is an exemplification of biographical learning. The text presents the results of the research project describing learning from one's own biography in the following perspectives: ontological, epistemological, methodological and methodical. It shows a person as a biographical being and displays the process of studying/exploring one's own biography and the process of cognition (of reality) through biography. Furthermore, the paper discusses three contexts of understanding and experiencing learning from one's own biography and methodical implications for adult education.
\end{abstract}

Keywords: learning from one's own biography, biographical learning, empirical studies, andragogy, adult education.

\footnotetext{
* Uniwersytet Łódzki, Wydział Nauk o Wychowaniu, Zakład Andragogiki i Gerontologii Społecznej.
} 


\section{Wprowadzenie}

Biografia i badanie biografii, w różnorodnych kontekstach, co najmniej od lat 80-tych XX w., interesuje polskich andragogów (por. Dubas 2011a: 5). Jeden z nurtów tych poszukiwań stanowi badanie biografii pod kątem uczenia się z własnej biografii. Projekt taki, właśnie pod nazwą „uczenie się z własnej biografii”, w latach 2008-2010, realizował zespół skupiający badaczy z wielu ośrodków akademickich w kraju ${ }^{1}$, pod kierunkiem dr hab. Elżbiety Dubas, prof. Uniwersytetu Łódzkiego, kierownika Zakładu Andragogiki i Gerontologii Społecznej Uniwersytetu Łódzkiego, którego pracownicy byli, jak dotychczas, organizatorami jedenastu biograficznych konferencji naukowych, poświęconych zagadnieniom związanym z badaniem biografii, w szczególności z perspektywy andragogicznej, ale także $\mathrm{z}$ udziałem badaczy reprezentujących inne dyscypliny naukowe, w tym psychologię i filozofię. Badania, o których traktuje poniższy tekst, zawiera głównie pierwszy tom z serii: „Biografia i badanie biografii”, pod tytułem Uczenie się z (własnej) biografii, wydany pod naukową redakcją Elżbiety Dubas i Wojciecha Świtalskiego (2011a).

Głównym celem projektu, merytorycznie umiejscowionego głównie w andragogicznej przestrzeni badawczej, było rozpozna(wa)nie procesów uczenia się z biografii. Szczególnie interesowało badaczy to, w jakiej mierze dorośli uczyli się i uczą, podejmując refleksję nad biografiami czy autobiografią. Ten kontekst badania biografii przede wszystkim łączy się z koncepcją biograficznego uczenia się i jest jej empiryczną egzemplifikacją. Autorską koncepcję biograficznego uczenia się prezentuje Peter Alheit (np. 1990, 2011). Także inni badacze odczytują ją w podobnym znaczeniu. Należy do nich Pierre Dominice (2006), Knud Illeris (2006), Agnieszka Bron (2009), a w Polsce w szczególności Olga Czerniawska (2000, 2007, 2011a, 2011b), Ewa Skibińska (2006), Danuta Lalak (2010), Elżbieta Dubas (2009, 2011a, 2011b, 2014b, 2015b), Emilia Mazurek (2013) i inni.

Uczenie się z biografii, w realizowanym projekcie, było analizowane jako uczenie się z własnej biografii (Dubas, Świtalski (red.) 2011a) oraz uczenie się z biografii Innych (Dubas, Świtalski (red.) 2011b). Przedmiotem rozważań w tym tekście uczyniono uczenie się z własnej biografii. Uczenie się z (własnej) biografii należy odróżnić od uczenia się z (własnych) doświadczeń. Uczenie się z doświadczeń jest uczeniem się w trakcie życia, w sytuacjach organizowanych lub incydentalnych, związanych z realizacją zadań życiowych i podejmowanymi aktywnościami czy też ich zaniechaniem. To uczenie się z doświadczeń - w sposób bezpośredni, tj. w trakcie dziania się zdarzeń, w trakcie trwania określonych sytuacji życiowych. Jest ono uczeniem się z doświadczeń własnych i doświadczeń Innych, pozostają-

\footnotetext{
$1 \mathrm{~W}$ projekcie „Uczenie się z własnej biografii” uczestniczyli: dr Beata Borowska-Beszta, dr Anna Frąckowiak, mgr Katarzyna Gajek, mgr Joanna Golonka, mgr Luba Jakubowska, dr Amelia Krawczyk-Bocian, mgr Emilia Mazurek, dr Joanna Wawrzyniak, dr Arkadiusz Wąsiński, mgr Magdalena Wnuk-Olenicz, dr Katarzyna Wypiorczyk-Przygoda, dr Joanna Wawrzyniak.
} 
cych w bezpośredniej styczności czasowo-przestrzennej jaką tworzą sytuacje. W tym kontekście, uczenie się z biografii jest uczeniem się pośrednim, bo z doświadczeń przypominanych, które miały miejsce często w odległej przeszłości i zapisały się w pamięci (auto)biograficznej (Dubas 2011a, 2: 7).

\section{Uczenie się z własnej biografii w świetle badań projektowych}

\section{Ontologiczne aspekty uczenia się z własnej biografii - Człowiek jako istota biograficzna}

Uczenie się z własnej biografii jest możliwe, ponieważ człowieka można opisać jako istotę biograficzną (homo biographicus). Biografia/autobiografia może istnieć jedynie dzięki pamięci; biografia jest poniekąd bezpośrednio (choć nie tylko) funkcją pamięci, w którą wyposażona jest ludzka istota. Biografia, a więc zapis doświadczeń w pamięci biograficznej, ale także świadomość biografii, tworzenie biografii to istotne właściwości, odzwierciedlające swoistość człowieczeństwa w porównaniu z innymi istotami żywymi. Człowiek w pewnym stopniu „opisany” jest przez swą biografię. Może także doświadczać biografii Innych.

Biografia jest konstrukcją myślową (myślaną, mówioną lub zapisaną na dowolnych nośnikach), która porządkuje, interpretuje i nadaje znaczenia doświadczeniom, które przeżyła jednostka w trakcie swego życia. Biografia zawiera pamięć doświadczeń życiowych, które odnoszą się do wydarzeń i sytuacji w życiu jednostki, które zostały przez nią przeżyte i zapamiętane, najczęściej jako ważne i znaczące, aktualnie zaś są pamiętane, przypominane lub mogą być przypomniane, i które formowały tożsamość jednostki na przestrzeni biegu jej życia, przy czym dalsza refleksja nad doświadczeniami życiowymi przywoływanymi z pamięci autobiograficznej wciąż dookreśla tożsamość jednostki (por. Dubas 2009: 41).

Biografię jednak nie tyle samoistnie „tworzą” doświadczenia życiowe jednostki, lecz to ona sama, choć warunkowana wpływami społeczno-kulturowymi, jest w mniejszym lub większym stopniu podmiotem konstruującym swą biografię. W tym przejawia się także jej podmiotowość i indywidualność, refleksyjność i zdolność do (auto)kreacji.

Uczenie się z własnej biografii uwypukla tezę, że człowiek jest istotą trudnych doświadczeń egzystencjalnych. Zapisywane są one w jego pamięci biograficznej i często przypominane. Doświadczenia te (wśród nich traumy, trajektorie, piętno, zwroty, sytuacje graniczne, przełomy biograficzne itp.) nie tylko obciążają jednostkę i przynoszą cierpienie, ale także mogą wzbudzać, a nawet wymuszać pracę biograficzną (np. pracę nad trajektorią), której efektem mogą być rekonstrukcje tożsamości, w tym transformacje dotychczasowych schematów i perspektyw poznawczych, pozwalające na akceptację siebie mimo i w wyniku trudnych doświadczeń, oraz na podejmowanie nowych decyzji życiowych pozwalających żyć 
bardziej satysfakcjonująco. Amelia Krawczyk-Bocian zauważa, że narracja biograficzna jest podróżą do świata przeżyć i doświadczeń, rozumianych z perspektywy czasu, i pozwala na ich bazie tworzyć „repertuar strategii radzenia sobie z troskami i zawiłościami życia” (2011a: 89). Uczenie się z własnej biografii sprzyja więc radzeniu sobie $\mathrm{z}$ troskami egzystencjalnymi immanentnie wpisanymi przecież w ludzki los.

Biografia zawiera nie tylko pamięć doświadczeń życiowych w ich warstwie obiektywnej, faktograficznej (life history), ale w biografii permanentnie rekonstruowanej zawiera subiektywne refleksje nad tymi doświadczeniami (life story). Obiektywna i subiektywna warstwa biografii łączą się w procesie uczenia się z biografii. Uczenie się z własnej biografii rozgrywa się gównie w polu rozbudowanego subiektywnego odbioru obiektywnych sytuacji życiowych, które stanowią punkt wyjścia dla tej refleksji.

Biografia/autobiografia jest „konstruktem pamięciowo-poznawczym o funkcjach regulacyjnych i osobowo-twórczych, porządkującym, wyjaśniającym, nadającym sens przeżytemu życiu oraz cel życiu przyszłemu" (por. Dubas 2011a, 1: 212). Biografię można uznać za strukturę regulacji tożsamości. Zdaniem Joanny Golonki, można wręcz mówić o regulacyjnych funkcjach biografii, które np. odnoszą się do porządkowania perspektyw czasowych i obszarów doświadczanego życia (Golonka 2011a: 173-174). W procesie uczenia się z własnej biografii, biografia immanentnie powiązana jest z tożsamością. Biografia i tożsamość tworzą wzajemnie dopełniający się układ: kryzys tożsamościowy przywołuje biografię, refleksja autobiograficzna modernizuje tożsamość.

Szczególny związek biografii z tożsamością uwidacznia się w kontekście niektórych silnie modyfikujących tożsamość struktur procesowych biografii. Należy do nich m.in. trajektoria. Katarzyna Gajek zwraca uwagę, że „trajektoria jako typ doświadczenia biograficznego jednostki, dokonuje transformacji tożsamości, poprzez zmianę sposobu postrzegania i oceniania siebie oraz partnerów interakcji". Autorka pisze też, że biograficzna praca nad trajektorią zaczyna się, gdy „człowiek może na nowo zdefiniować własną sytuację życiową”. Poprzez pracę biograficzną nad trajektorią jednostka odzyskuje tożsamość, rekonstruuje tożsamość (Gajek 2011a: 50). „Konstruowanie tożsamości jest niekończącym się procesem definiowania siebie przez pryzmat interakcji z innymi ludźmi" (tamże: 49). Związki biografii i trajektorii w procesie uczenia się z biografii wyraźnie unaoczniają wyniki badań Emilii Mazurek dotyczące doświadczeń kobiet z chorobą nowotworową piersi (Mazurek 2011a, 2013).

Uczenie się z własnej biografii ukazuje też dobitnie, że biografia jest otwartym projektem tożsamościowym. Czasy intensywnych zmian zewnętrznych (społecznych, kulturowych, cywilizacyjnych) wymuszają także zmiany wewnętrzne (podmiotowe), które pozwalają jednostce na odnalezienie się w sytuacji zmian. Biografia jest dziś coraz częściej projektem tożsamościowym, permanentnie podejmowanym przez jednostkę. Cechą biografii współczesnej jest jej duża dynamika, w prze- 
ciwieństwie do statycznych biografii tradycyjnych. Praca z biografią, w wyniku której konstruowana jest zmodyfikowana tożsamość jednostki, ma nadążać za zmianą jako powszechnym fenomenem życia we współczesnych wysoko rozwiniętych społeczeństwach. Uczenie się z własnej biografii chroni tożsamość przed zagubieniem, erozją i rozpadem.

Z perspektywy procesu uczenia się z własnej biografii można dostrzec dwie postawy wobec własnej biografii. Człowiek jako istota biograficzna może przyjmować określoną postawę wobec własnych doświadczeń życiowych. Postawa pasywna odzwierciedla zapamiętywanie doświadczeń, często mimowolnie, podświadomie, oraz odtwarzanie biegu wydarzeń życiowych, zasadniczo w sposób faktograficzny, zgodnie z czasem chronologicznym - linearnie, czasem w powiązaniu z ich kontekstem społeczno-kulturowym. Postawa pasywna charakteryzuje jednostki w społeczeństwach tradycyjnych, gdzie oczekiwane są biografie typowe, odzwierciedlające bieg jednostkowego życia, który jest odpowiedzią na obiektywnie stanowione społeczne normy i wartości. Postawa aktywna (czynna) wiąże się natomiast z wyraźną refleksją autobiograficzną, narracją biograficzną, częstą lub permanentną konstrukcją, rekonstrukcją i autokreacją własnej tożsamości poprzez tę refleksję i narrację, tworzeniem wiedzy autobiograficznej (implikowanej), samodzielnie wydobywanej z własnego doświadczenia biograficznego. Aktywna postawa wobec własnej biografii ukazuje przenikanie się wielu perspektyw czasowych i zakotwiczanie się jednostki w złożonej orientacji czasowej (por. np. Dubas: w druku, t. 5). Arkadiusz Wąsiński tak określa przemieszczanie się przestrzeni czasowych w refleksji i autokreacji biograficznej: „Wartościując swą przeszłość (narrator; przypis Autora), otwiera się na przyszłość, kreując (w teraźniejszości) narracyjnie ustrukturyzowany system znaczeń i sensów" (2011a: 40). Postawa aktywna wobec biografii jest też wyrazem subiektywnego, podmiotowego odbioru doświadczanej rzeczywistości; w tej postawie odzwierciedlony jest w pełni subiektywny wymiar biografii. Taka postawa częściej obecna jest wśród osób żyjących w społeczeństwach współczesnych pluralistycznych i z elementami kultury ponowoczesnej.

Biografia niewątpliwie łączy się z metaforą drogi. Biografia często odzwierciedla doświadczanie życia jako przemierzanie „drogi” rozumianej nie tylko w sensie topograficznym (obiektywnym), ale nade wszystko $\mathrm{w}$ sensie metaforycznym (subiektywnym), a człowieka - posiadacza biografii ukazuje jako „wędrowca”, w tych samych znaczeniach (obiektywnym i subiektywnym). Określanie więc biografii jako opisu życia - drogi życia, opisu losu ludzkiego też można uznać za zasadne; choć ogólne - to jednak bardzo obrazowe. Badanie, poznawanie własnej biografii poprzez narrację biograficzną, refleksję biograficzną, nowe interpretacje doświadczeń biograficznych to poniekąd wielokrotne przemierzanie już przebytych dróg życia, to mentalne powroty do wydarzeń z przeszłości, realizowane dziś, także z myślą o (bardziej pomyślnej) przyszłości. To swoiste spotykanie się jeszcze raz z tym, co wydarzyło się dawniej, jednak w inny sposób, bo zmodyfikowany nowym doświadczeniem biograficznym. Uczenie się z własnej biografii to swoista mentalna 
podróż w czasie sprzyjająca głębszemu poznaniu i rozumieniu, nie tylko siebie samego.

Uczenie się z własnej biografii wyraźnie łączy się z wątkiem autokreacji i autoformacji osoby posiadacza biografii. Autobiografię z autokreacją wiąże np. Kamila Lasocińska (2014). Wątek autokreacji w powiązaniu z narracją i refleksją biograficzną podkreśla wyraźnie Arkadiusz Wąsiński. Narracja biograficzna jest podłożem autokreacji - tworzenia siebie. Sprzyja odpowiedziom na pytania: Kim jestem? Po co jestem? Jaki mogę być? Zwraca uwagę złożoność refleksji w procesie autokreacji, i to, że łączy ona ze sobą perspektywę egzystencjalną, aksjologiczną i autobiograficzną, która oznacza „rozpoznanie i interpretowanie znaczeń przyjętych przez podmiot jako kluczowe dla rozumienia własnej biografii" (Wąsiński 2011a, 1: 40). Autokreacja, w kontekście narracji i refleksji biograficznej, ma charakter myślenia kontemplacyjnego, poszukującego i projektującego (tamże). Trzeba zaznaczyć, że traktowanie biografii jako tworzywa autokreacji uwypukla podmiotowy charakter ludzkiej biografii, jej zmienność i „przetwarzalność”. Ukazuje dynamiczną biografię jako istotne, jeszcze jedno źródło tworzenia siebie i autoformacji.

Autokreacyjne kompetencje, wzbudzane i rozwijane w kontekście namysłu nad własną biografią, służą w końcowym efekcie bardziej pomyślnemu kierowaniu własnym życiem, skuteczniejszemu i bardziej satysfakcjonującemu radzeniu sobie z własnym życiem. Biografia jest więc kanwą dla procesu kierowania własnym życiem.

Biografia jest także przestrzenią spotkania z samym sobą. Kontakt z własną biografią jest bliskim osobowym kontaktem z samym sobą (Ja - ja biograficzne). Zdaniem Amelii Krawczyk-Bocian, narracja biograficzna jest właśnie spotkaniem z samym sobą, jest poszukiwaniem własnej tożsamości, samookreślaniem siebie (2011a: 88). Takie spotkanie $\mathrm{z}$ samym sobą poprzez własną biografię wymaga wysiłku poznawczego - spojrzenia na siebie jakby z boku, z czasowego dystansu wobec własnych doświadczeń, z perspektywy przeszłej, a aktualnej wiedzy i samowiedzy. Takie spotkanie sprzyja modyfikacji samooceny i własnych oczekiwań. W tym sensie ma w pełni znamiona biograficznego uczenia się, w szczególności uczenia się z własnej biografii.

Biografie bywają całościowe lub tematyczne. Namysł nad własną biografią może bowiem obejmować całość życiowego doświadczenia jednostki albo wybrane jego części (fragmenty). Biografie całościowe często, choć nie zawsze, są uporządkowane chronologicznie. Ukazują, w sposób niekiedy bardzo klarowny, sens jednostkowych życiowych doświadczeń, które spostrzegane są z perspektywy całego życia, tworząc swoisty jego bilans, choć może nie brakować w nim wątpliwości i znaków zapytania (por. np. Dubas 2011a, 1; Wnuk-Olenicz 2011a; Dubas: w druku, t. 5). Klarowna konstrukcja własnej biografii wskazuje na życie przemyślane, na odczytanie jego sensu, rozpoznanie misji życiowej, zrozumienie znaczenia poszczególnych części drogi życiowej dla jej całości, na myślenie autobiograficzne nastawione na kierowanie życiem i swoim rozwojem, na wysoką świadomość 
autobiograficzną, pożytkowaną dla autokreacji tożsamości, na akceptację swego losu i swej roli życiowej. Biografie takie konstruowane są przez osoby refleksyjne, w dużym stopniu samoświadome i pragnące tę samoświadomość jeszcze poszerzać, osoby, które często w ostatecznej ocenie pozytywnie bilansują swoje życie. Biografie tematyczne wywoływane są często ważnymi, znaczącymi życiowymi doświadczeniami, nieraz trudnymi i wciąż nierozwiązanymi lub rozwiązanymi po długim czasie. Namysł biograficzny służy tu poszukiwaniu przyczyny zaistniałych sytuacji życiowych, także w szerszym kontekście, np. historycznym (Dubas 2011b: 77 i n.), zrozumieniu siebie i innych $\mathrm{w}$ tych sytuacjach, wyzwoleniu się $\mathrm{z}$ traumy trudnego doświadczenia, pozwala na wybór dalszej drogi życiowej i bardziej optymalnych strategii postępowania. Konstruowanie biografii nie tylko porządkuje dotychczasową wiedzę biograficzną, lecz także często sprzyja wydobywaniu nieuświadomionych rezerwuarów pamięci biograficznej. Wiedza utajona, nieuświadomiona (tacit knowledge) od tego momentu staje się wiedzą uświadomioną, wydobytą i przydatną dla dalszej pogłębionej refleksji biograficznej. To niepodważalny efekt uczenia się z własnej biografii.

\section{Epistemologiczne aspekty w badaniu uczenia się z własnej biografii}

W kontekście epistemologicznym uczenie się z własnej biografii odzwierciedla dwa główne procesy: proces poznania, a raczej poznawania, własnej biografii, tzn. zaznajamiania się z nią, czynienia jej bardziej świadomą, oraz proces poznawania poprzez biografię - poznawania nie tylko siebie, ale także szerszej rzeczywistości, której doświadczała jednostka. Pierwszy aspekt uczenia się z biografii uwzględnia struktury procesowe biografii, ponieważ proces poznawania biografii łączy się $\mathrm{z}$ rozpoznaniem tych struktur w biografii. Poza klasycznymi strukturami procesowymi, za Fritzem Schütze i Gerhardem Riemannem (Schütze 1983, 1997; por. też wykaz: Dubas 2015: 37-38), a więc biograficznymi schematami działania - planami przebiegu życia, instytucjonalnymi wzorcami przebiegu życia, metamorfozami i trajektoriami cierpienia, można wymienić też floating, przejścia - pasaże - tranzycje, „przełomy” biograficzne, znaczące wydarzenia życiowe osobiste i globalne, sytuacje trudne, traumy biograficzne, detale i epizody biograficzne, fakty biograficzne, warstwę subiektywną biografii, epifanie, tematyczne linie biografii, linie biografii edukacyjnej, polaryzacje światów życia (Dubas 2011a, 1: 209), piętno (Kostrzyńska 2011b), kotwice biograficzne (Walulik, Krzysztofek: w druku, t. 5). Niektóre z tych struktur mają charakter bardziej statyczny niż pozostałe (dotyczy to np. epizodów biograficznych, wydarzeń granicznych, „ram” odzwierciedlających biograficzne schematy działania, instytucjonalnych wzorców przebiegu życia, „kotwic” biograficznych, piętna, przełomów biograficznych, polaryzacji światów życia, epifanii, floatingu), gdy umiejscowione są w jednym punkcie czasoprzestrzeni, gdy są wielokrotnie tak samo przytaczane w opowieściach biograficznych, gdy 
stały się kanwą dla refleksji autobiograficznej podejmowanej przez dłuższy czas. Inne struktury procesowe biografii, takie jak np. trajektorie, metamorfozy/transformacje, tranzycje/pasaże, balansowanie, mają dynamiczny charakter, gdyż są rozłożone $\mathrm{w}$ czasie, wiążą się z dużym ładunkiem subiektywizmu $\mathrm{w}$ ich odbiorze, są przedmiotem intensywnej refleksji autobiograficznej oraz wielokrotnych (re)interpretacji. Między strukturami procesowymi biografii można rozpoznać różnorodne powiązania, tworzące łańcuchy struktur biograficznych. Do typowych należą np. powiązania między przełomami biograficznymi, trajektorią a metamorfozą. Uczenie się z własnej biografii odzwierciedla wysiłek łączenia różnych struktur biograficznych, poprzez proces odczytywania znaczeń doświadczeń biograficznych, w celu redefinicji tożsamości sprzyjającej (np. w skutek pozbycia się traumy czy piętna) odzyskiwaniu sensu życia. Istotne powiązania w biografii tworzone są też między jej częściami (tematami) a całością opisu drogi życiowej. Często takie łączenie możliwe jest z perspektywy bilansowania długiego przeżytego życia, gdy sens życia łatwiejszy jest do rozpoznania.

Modyfikacjom tożsamości poprzez biografię, a więc poprzez namysł nad biografią i jej interpretacje, sprzyjają elementy biograficznej regulacji tożsamości. Można do nich zaliczyć: doświadczenia życiowe, wiedzę biograficzną, konstruowanie biografii, autobiograficzną refleksyjność, potencjał interpretacyjny, kompetencję autobiograficzną, autoformację, autokreację, kierowanie własnym życiem (por. Dubas 2009: 42-43). Są to zarazem istotne uwarunkowania i etapy biograficznego uczenia się, w tym uczenia się z własnej biografii.

Doświadczenia życiowe to podstawowy składnik biografii. Cechuje je powszechna obecność w biografiach. Z jednej strony są one uzależnione od tła społeczno-historycznego, z drugiej zaś, wyraźny jest ich subiektywny kontekst. Dzięki pamięci doświadczane sytuacje mogą być zapamiętywane i przypominane, ale także zapominane. Już sam fakt zapamiętania określonych wydarzeń życiowych wskazuje na doświadczenie ich przez jednostkę, z jakiegoś ważnego dla niej powodu, jako znaczących. Pamiętanie, przypominanie i reflektowanie przez jednostkę określonych doświadczeń życiowych wskazuje na ich znaczenie dla kształtowania jej tożsamości. Zawierają one pewną wiedzę i umiejętności, ważne dla jednostki, „odkładające się w trakcie życia jako wiedza biograficzna” (Hoerning 1989, cyt. za: Schlüter 2004: 11). Wiedza biograficzna nie jest wiedzą gotową, często jest nieuporządkowana i uświadomiona jedynie fragmentarycznie. W procesie uczenia się z własnej biografii może się stać jednak wiedzą uświadomioną, wydobytą z pokładów wiedzy uśpionej (tacit knowledge); staje się wiedzą implikowaną. Wiedza biograficzna to nie tylko wiedza wywiedziona bezpośrednio z doświadczeń życiowych wtedy, kiedy się działy, ale to także wiedza budowana na bazie wielokrotnych refleksyjnych powrotów do tych doświadczeń. Wiedza biograficzna „to kapitał wykorzystywany do konstruowana biografii" (Schlüter 2004: 12). Konstruowanie biografii to pewna zdolność „stała i powtarzalna” (Hoerning 1989, cyt. za: Schlüter 2004: 11), pozwalająca na poszerzanie wiedzy biograficznej (Schlüter 2004). Jak 
pokazuje projekt „Uczenie się z własnej biografii”, konstruowanie autobiografii jest umiejętnością, którą można wzbudzić, ćwiczyć i doskonalić. Uczenie się z własnej biografii ukazuje też umiejętność konstruowania biografii jako proces rozłożony w czasie, powiązany z biegiem życia i pojawiającymi się nowymi życiowymi wyzwaniami.

Wiedza biograficzna, poszerzana i pogłębiana, wymaga autobiograficznej refleksyjności, rozumianej jako umiejętność namysłu nad własnymi doświadczeniami biograficznymi. Cechą charakterystyczną tej refleksyjności jest odnoszenie się do wszystkich wymiarów czasu: przeszłości, teraźniejszości i przyszłości, często także, szczególnie w późniejszym wieku lub w sytuacjach granicznych - do czasu transcendentalnego. Refleksję autobiograficzną umożliwia potencjał interpretacyjny (Schlüter 2004: 12). Oznacza on pewną ludzką możliwość, predyspozycję do wyjaśniania, oceniania i interpretowania doświadczeń życiowych. W kontekście tej predyspozycji doświadczenia życiowe, wraz z namysłem nad nimi, uzyskują swą dynamikę i subiektywny charakter, by w coraz bardziej znaczący sposób włączać się w proces dookreślania i modernizacji tożsamości. Refleksja autobiograficzna to istotny składnik kompetencji biograficznej (Pietrasiński 1990: 142-144), którą można rozumieć jako umiejętność uczenia się z doświadczeń zawartych we własnej biografii, jak i w biografiach innych ludzi. To także umiejętność czerpania wiedzy z doświadczeń, gdy aktualnie się dzieją, co oznacza dostrzeganie z perspektywy teraźniejszości ich znaczenia dla aktualnego i przyszłego życia. To także umiejętność dzielenia się wiedzą biograficzną z innymi, co często stawia jednostkę w pozycji mentora, doradcy, świadka losu. Refleksja (auto)biograficzna szczególnie uwidacznia się (por. też Dubas 2009: 46-49) w trudnych doświadczeniach życiowych, takich jak sytuacje krytyczne, doświadczane troski egzystencjalne, przełomy życiowe, doświadczenia trajektoryjne, metamorfozy, a także w pewnych okresach życia, które szczególnie skłaniają do dokonywania bilansu życiowego czy podejmowania ważnych decyzji i wyborów. Taka refleksja autobiograficzna często zawiera duży ładunek emocjonalny; narracje autobiograficzne ujawniają obecność silnych emocji w przeszłości i aktualnie. Wydarzenia, których refleksja dotyczy/ła, były i są zazwyczaj ważnymi wydarzeniami z perspektywy biegu całego życia jednostki. Te elementy biografii mają też silny potencjał edukacyjny, który jednak wymaga „wydobycia”, uświadomienia, często z udziałem osób z zewnątrz, w tym badacza biografii.

Kompetencja biograficzna sprzyja kierowaniu własnym życiem poprzez wykorzystywanie wiedzy biograficznej, często powiązanej z mądrością życiową, dla pełniejszego własnego rozwoju i realizacji życia jako bardziej pomyślnego. Kierowanie własnym życiem, z wykorzystaniem kompetencji biograficznej, uwzględnia różne procesy edukacyjne, w tym w szczególności autoformację i autokreację, które są istotnymi elementami samowychowania w szerokim znaczeniu. Ujawniają one wyraźnie edukacyjny wymiar biografii i jej edukacyjne funkcje. 
Podsumowując, z perspektywy uczenia się z własnej biografii doświadczenia życiowe stanowią bazę/tworzywo/punkt wyjścia dla tego uczenia się. Poddane biograficznej refleksyjności osoby wyposażonej $\mathrm{w}$ potencjał interpretacyjny, sprzyjają (z)rozumieniu życia. W następstwie wyzwalają działania autoformacyjne i autokreacyjne, co ułatwia autorskie kierowanie własnym życiem, sprzyjające doświadczaniu poczucia sensu życia. Tożsamość posiadacza biografii staje się pełniejsza, zrównoważona, dojrzalsza, co „pozwala na dokonywanie wyborów i konsekwentne podążanie wybraną drogą życiową, czyni go też gotowym do podejmowania konsekwencji własnych działań, do odpowiedzialności za siebie i innych ludzi, powierzonych jego opiece" (Bardziejewska w: Brzezińska 2005: 370)².

Prowadzone badania w ramach projektu „Uczenie się z własnej biografii” ujawniły pewne szczegółowe konteksty poznawcze „otwierane”, uruchamiane przez badanie biografii, w tym przez wzbudzoną refleksję autobiograficzną.

Należy do nich zaliczyć rozpoznanie (i uznanie) narracji autobiograficznej jako procesu poznawania rzeczywistości, której narrator doświadcza/ł, jak i również poznawanie siebie samego. „Narracja jest płaszczyzną rozumienia życia (...) Narrator określa sens i znaczenie przeżytych zdarzeń. (...) narracja jest oglądem własnego wnętrza i zmian, jakie w jego obrębie się dokonały". Narracja biograficzna poszerza płaszczyznę dotychczasowego rozumienia życia jako procesu poznawania, także poznawania siebie samego (Krawczyk-Bocian 2011a: 88-89). To poznawanie świata i siebie dotyczy także badacza. „Każde przeprowadzone badanie jest elementem biografii badacza, zatem również może być ważnym obszarem uczenia się" (Jakubowska 2011a: 194).

Narracja autobiograficzna jest także płaszczyzną zderzania się świata wiedzy naukowej i potocznej (por. np. Krawczyk-Bocian 2011a). Narrator dostarcza zazwyczaj wiedzy potocznej, która zderzana jest z wiedzą naukową badacza, który jako człowiek również doświadcza wiedzy potocznej. Badanie biografii sprzyja także wytwarzaniu wiedzy zarówno w trakcie namysłu biograficznego podczas wywiadu, jak i po jego zakończeniu. Wiedza implikowana (wytwarzana), a nie eksplikowana (gotowa) wydaje się, że bardziej odpowiada podmiotowości człowieka dorosłego jako uczącego się (por. Frąckowiak 2011a).

Kolejny kontekst poznawczy badania biografii stanowi rozpoznanie trajektorii jako struktury procesowej biografii, która może uruchomić biograficzne uczenie się (por. np. Mazurek 2011a; Gajek 2011a; Dubas 2014b). Emilia Mazurek zauważa, że: „Trajektoria może sprzyjać odkrywaniu wiedzy egzystencjalnej, niezbędnej do funkcjonowania w nowej rzeczywistości. Jest to wiedza zdobyta przez odczuwanie, doświadczanie i działanie (...) Wynika z krytycznej refleksji nad doświadczeniami,

\footnotetext{
2 Definicja w ujęciu Bardziejewskiej dotyczy adolescenta, który w końcowej fazie rozwoju swej tożsamości osiąga/może osiągnąć tożsamość dojrzałą. Jednak definicja ta może być odniesiona do człowieka i w późniejszym okresie życia - w okresie dorosłości i starości. Tożsamość bowiem coraz częściej jest „permanentnym projektem”. Uwidacznia się to w procesie uczenia się z własnej biografii. Bycie (formalnie) dorosłym stymuluje do stawania się coraz bardziej dojrzałym.
} 
a przez to jest osobista, intymna, autobiograficzna, nastawiona na pragmatyzm" (Mazurek 2011a: 67). By trajektoria była uczeniem się i twórczą, rozwojową zmianą sytuacji, wymaga „akceptacji własnej choroby i rozumienia sensu cierpienia, ból może wzbogacić wewnętrzne życie człowieka, a przez to wzbogacić jego aktywność twórczą. (...) Można przypuszczać, że nie tyle sama choroba, co wypracowane strategie radzenia sobie $\mathrm{z}$ nią zawierać będą potencjał rozwojowy" (Mazurek 2011a: 66). Uczenie się „spowodowane” trajektorią jest zazwyczaj umiejscowione w nurcie uczenia się nieformalnego, sytuacyjnego, konstruktywnego, transformatywnego, biograficznego. Jest umiejscowione w codzienności (Mazurek 2011a: 51).

W procesie uczenia się z własnej biografii ważną rolę odgrywa potencjał intelektualny narratora (por. Borowska-Beszta 2011a). Jest on jednym z warunków tego uczenia się, obok specyfiki interakcji, jaka powstaje w procesie badania biograficznego, którą można określić jako spotkanie osób (badacza i badanego). Zdaniem Beaty Borowskiej-Beszty, im potencjał intelektualny narratora wyższy, tym uczenie się z własnej biografii bardziej konstruktywne (Borowska-Beszta 2011a: 118). Mimo wysokiego potencjału intelektualnego narratorów, proces uczenia się z biografii ujawniał się stopniowo. Borowska-Beszta pisze: „Dochodzenie do kwestii uczenia się było zatem stopniowym procesem interakcyjnym (...) Nie ujawniało się od początku rozmowy, lecz było stopniowo dekodowane przez autorefleksję narratora. Wiązało się z przypominaniem, werbalizowaniem uprzednio zreflektowanych faktów i zjawisk z własnej biografii i życia” (Borowska-Beszta 2011a: 119). Wywiad narracyjny, zauważa Wąsiński, „mający charakter ukierunkowanej problemowo retrospekcji wydarzeń”, skłania narratorów do pogłębionej intelektualnie autorefleksji, w której widoczny jest język uczuć i namysł, prowadzący do autokreacji, nawet jeśli nie jest ona bezpośrednio wiązana z uczeniem się z własnej biografii (Wąsiński 2011a, 2: 160-161). Należy dodać, że badani podejmujący refleksję autobiograficzną w projekcie „Uczenie się z własnej biografii” najczęściej legitymowali się wykształceniem wyższym lub co najmniej średnim. Najprawdopodobniej taki poziom wykształcenia narratora, gwarantując bardziej rozbudzoną jego świadomość i samoświadomość, pozwala na bardziej wnikliwą autorefleksję.

Narracja biograficzna odzwierciedla indywidualny sposób spostrzegania świata i siebie przez narratora. Odbiór ten może różnić się od wiedzy, oczekiwań i doświadczeń badacza (por. np. Borowska-Beszta 2011a). Badanie (własnej) biografii odzwierciedla równocześnie zindywidualizowany proces poznawania świata i siebie samego, dynamiczny, zmieniający się w trakcie i po narracji. Umiejętność przyjęcia (zrozumienia?) tej odmiennej perspektywy widzenia świata i jednostkowego losu narratora może być przyczyną transformacji dotychczasowych schematów i perspektyw poznawczych u badacza. Uczenie się z własnej biografii jest niewątpliwie fenomenem zindywidualizowanym, dziejącym się na bazie jednostkowych doświadczeń życiowych i indywidualnych predyspozycji w zakresie biograficznej refleksyjności i potencjału interpretacyjnego, a także na 
bazie jednostkowych schematów uczenia się/poznawania. Można jednak wskazać pewne ogólne prawidłowości tego procesu. Stanowi je duża dynamika procesu uczenia się z własnej biografii, jego wysoka emocjonalność, wielokrotne powroty refleksji autobiograficznej skoncentrowanej na temacie (np. wokół jakiegoś istotnego dla jednostki doświadczenia), zmierzanie ku lub/i osiągnięcie konkluzji (zrozumienia, dostrzeżenia sensu, rozwiązania „tematu”). Istotą tego procesu jest pozyskanie jakiejś wiedzy, która przydatna jest właśnie tej jednostce $w$ dalszym, bardziej optymalnym życiu - w radzeniu sobie z życiem.

Niewątpliwie temu procesowi sprzyja osobowość autorefleksyjna (Dubas 2009, 2011a): ciekawa świata, innych ludzi i siebie samej - ciekawa życia, aktywna edukacyjnie - z rozbudzonymi potrzebami uczenia się, rozumianymi jako poznawanie, otwarta na zmiany, poszukująca nowych rozwiązań, znaczeń i sensów, twórcza w zakresie swej tożsamości i drogi życiowej.

Badanie biografii realizowane w projekcie „Uczenie się z własnej biografii” ujawniło trzy konteksty rozumienia i doświadczania uczenia się z własnej biografii. Pierwszy - to uświadomiony proces uczenia się z własnej biografii, drugi - to uczenie się z własnej biografii raczej nieobecne i nieuświadomione, trzeci - uczenie się z własnej biografii tożsame lub zbliżone znaczeniowo do uczenia się z doświadczeń.

Uczenie się z własnej biografii jako proces uświadomiony (przykłady: Borowska-Beszta 2011a; Jakubowska 2011a; Golonka 2011a) ujawnia wzbudzoną refleksję nad doświadczeniami życiowymi, w tym w szczególności tymi negatywnymi, często związanymi z traumą biograficzną, towarzyszącą jednostce przez wiele lat życia, często od dzieciństwa. Refleksja ta zmierza ku odkryciu i rozpoznaniu mechanizmów poznawczo-emocjonalnych, kierujących odbiorem świata, których korzenie umiejscowione są często właśnie w początkach życia - w dzieciństwie. Taka pogłębiona refleksja możliwa jest dopiero w dorosłym życiu, gdy jednostka świadomie pracuje nad relacjami z innymi i planuje swoją przyszłość. Jak pisze Beata Borowska-Beszta, dzieciństwo to jeszcze brak zreflektowanego uczenia się z własnej biografii, a w adolescencji pojawiają się początki takiej refleksji. Refleksja autobiograficzna sprzyjająca uczeniu się z własnej biografii rozwijana jest stopniowo, z dużym zaangażowaniem, w tym emocjonalnym jednostki (Borowska-Beszta 2011a: 118-119). Uczenie się z własnej biografii charakteryzuje osobę umiejętnie łączącą w refleksji autobiograficznej różne perspektywy czasowe oraz części biografii w całość, odnajdującą sens swego życia oraz motywację do zmian swego dotychczasowego sposobu doświadczania życia - „bycia w życiu” (np. w zakresie relacji z innymi, własnej samooceny i pozycji społecznej itp.). Uczenie się z własnej biografii poprzedza wcześniejsza refleksja nad doświadczeniami życiowymi, której celem jest uporządkowanie i wyjaśnienie (np. odkrycie przyczyn, zrozumienie) indywidualnego doświadczenia życiowego. Uczenie się z własnej biografii wiąże się z procesem motywowania do zmian w życiu i modyfikacji własnej tożsamości. Uczenie się z własnej biografii niesie odpowiedzi na kluczowe pytania tożsamo- 
ściowe: Kim jestem? Dlaczego jestem taki? Kim mogę się stać?, a w efekcie odpowiedź na zasadnicze pytanie egzystencjalne: Jak żyć, by być szczęśliwym?

Nieuświadomione uczenie się z własnej biografii (przykłady: Wąsiński 2011a, 2; Dubas 2011a) dotyczy narratorów, którzy przypominają, często i z dużą precyzją, własne doświadczenia życiowe i związane z nimi myśli i uczucia. Jednak nie dostrzegają wprost ich związku z uczeniem się z własnej biografii. Między innymi nadmiar silnych emocji, obecnych w doświadczeniu (np. adopcji), wyjątkowość tego doświadczenia powodują, że „nie mogą one stanowić podstawy do uczenia się" (narrator Pierre w: Wąsiński 2011a, 2: 161). Spostrzegają natomiast uczenie się z doświadczeń, np. jako uczenie się pragmatyczne życiowo, „przydatne do uniknięcia błędów w analogicznych sytuacjach życiowych" (narrator Pierre, tamże) czy określają doświadczenia jako „znaczące źródło informacji o sobie samej, dzięki którym o wiele lepiej rozpoznaję swoje możliwości i czuję się wewnętrznie ubogacona" (narratorka July w: Wąsiński 2011a, 2: 161).

W potocznym rozumieniu określenie „uczenie się z własnej biografii” jest zbliżone albo tożsame znaczeniowo z określeniem „uczenie się z doświadczeń”. Bywa wyjaśniane dość lakonicznie i ze wskazaniem na zazębianie się obu znaczeń, np. uczenie się z własnej biografii jest określane jako „przemyślenia nad swymi doświadczeniami" (przykłady w: Dubas 2011a; Frąckowiak 2011a; Wąsiński 2011a, 2). Termin „uczenie się z doświadczeń” jest powszechnie rozumiany jako termin silnie osadzony w codzienności i w potocznym języku, tak jak i doświadczenie jest pojęciem bardziej „codziennym” niż biografia. Jednak należy dostrzec różnicę w znaczeniach tych kategorii pojęciowych (Dubas 2011a, 2). Uczenie się z biografii jako uczenie się $\mathrm{z}$ wielokrotnie reflektowanej i interpretowanej biografii, a nie uczenie się z doświadczeń dziejących się aktualnie, jest procesem bardziej świadomego i konstruktywistycznego, z perspektywy czasu i odniesień do wielu przestrzeni temporalnych, pożytkowania własnych doświadczeń, zapisanych w pamięci biograficznej dla własnego rozwoju, w tym autoformacji i autokreacji. Taki rodzaj uczenia się, niewątpliwie ważny jako sposób modyfikacji tożsamości, wymaga działań uświadamiających, np. w ramach dydaktyki biograficznej.

\section{Metodologiczne wskazania w badaniu uczenia się z własnej biografii}

Istotny i dość jednoznaczny wniosek, jaki wynika z realizacji badań nad zagadnieniem uczenia się z własnej biografii, potwierdza ogólną konstatację, że badanie biografii jest sztuką. Danuta Urbaniak-Zając pisze, że „Analiza biografii mająca naukowe aspiracje jest szczególnie trudną sztuką”, szczególnie gdy celem badań biograficznych jest empiryczne potwierdzanie teorii (Urbaniak-Zając 2011a: 25). Sztuka badań biograficznych nie wyklucza jednak stosowania metody. „Zalecenie łączenia metody i sztuki tylko pozornie brzmi jako paradoks - wydaje się, że w badaniach humanistycznych zawsze ma miejsce (...) metoda nie jest samoczynna, 
może być skuteczna wyłącznie dzięki wyobraźni i wrażliwości badacza" (tamże). Autorka, cytując Theodore Schulze, podkreśla, że badania biograficzne „dostarczają głównie wiedzy o detalach, a sztuka analizy polega na tym, by do bogatych w nawiązania detali znaleźć kolejne do nich pasujące, a stworzoną całość włączyć w szeroki kontekst" (tamże: 26). Urbaniak-Zając podkreśla niezbędną otwartość badacza w procesie badania biografii: „Umiejętności badawcze wzrastają wraz z doświadczeniem, pod warunkiem, że nie staje się ono rutyną, że analiza każdego kolejnego materiału (auto)biograficznego otwarta jest na niespodziankę" (tamże: 25). Zrealizowane $\mathrm{w}$ projekcie badania $\mathrm{w}$ pełni potwierdzają te stwierdzenia. Rzetelne stosowanie wybranej metody lub metod, połączone z intuicją, wrażliwością i twórczością badacza, przynosiło efekt bardziej pogłębionego poznania doświadczeń badanych osób i zbliżało badacza do (z)rozumienia ich wyjątkowego, jednostkowego losu umiejscowionego w szerszym tle społeczno-kulturowo-historycznym.

Badanie biografii pod kątem uczenia się z własnej biografii jest sytuacją badawczą, którą można określić jako wieloaspektowe spotkanie: badacza z badanym, badanego z samym sobą - poprzez przypominane, reflektowane i interpretowane własne doświadczenie życiowe, wydobywane z pamięci autobiograficznej. Jest to także spotkanie badacza z samym sobą. Beata Borowska-Beszta stwierdza, że spotkanie badacza i badanego jest komunikacją „na planie intelektualnym - werbalnym i emocjonalnym”, o kreacyjnej sile „wiążącej u podstawy komunikację i więź międzyludzką", wyzwalającym nieplanowaną autorefleksję nad fenomenem uczenia się z własnego życia (Borowska-Beszta 2011a: 120). Refleksja ta może trwać jeszcze przez jakiś czas po odbytym wywiadzie (tamże), może silnie mobilizować badanego do dalszej refleksji autobiograficznej i rewizji swojego stosunku do siebie samego (Dubas: w druku, t. 5), może być podejmowana także nad materiałem autobiograficznym po transkrypcji i autoryzacji (Golonka 2011a: 171). Spotkanie badanego z samym sobą, w kontekście narracji autobiograficznej, jest poszukiwaniem własnej tożsamości, jest samookreślaniem siebie (Krawczyk-Bocian 2011a: 88-89). To samo może dotyczyć badacza (Jakubowska 2011a), który dookreśla swą tożsamość zarówno jako osoba, jak i jako badacz (Dubas 2015). Relacja między badanym i badaczem ma charakter oddziaływań wzajemnych, „dwuwektorowych” (Borowska-Beszta 2011a: 121), choć o różnych treściach i natężeniu.

Pozycja badacza w badaniach biografii jest także określona przez szczególną specyfikę. Przede wszystkim badacz, który ma zapewnioną swą podmiotowość z racji bycia metodologicznym ekspertem sytuacji badawczej, winien być również gwarantem podmiotowości badanego. Amelia Krawczyk-Bocian pisze w tym kontekście o „dwubiegunowości” tej relacji (Krawczyk-Bocian 2011a: 88). Przygotowanie merytoryczne badacza do badań jest oczywistością, ale warto zwrócić uwagę, za Beatą Borowską-Besztą, na jego przygotowanie emocjonalne „na ekspozycje różnorodnych stanów emocjonalnych osób badanych", przygotowanie na 
„werbalne dotykanie”, odzwierciedlające różne poziomy intymności w relacji badawczej (Borowska-Beszta 2011a: 120). Badanie biografii jest niewątpliwie spotkaniem z intymnym i tajemniczym światem drugiej osoby - badacz więc powinien, w jakimś zakresie, być gotowym do relacji zawierającej intymne wątki, których nie powinien traktować jako interesujące nowinki, ale z pełną moralną odpowiedzialnością, w zgodzie z etyką badacza (biografii) (Dubas 2015: 43-45).

W sytuacji badania biografii można odnaleźć szczególny aspekt relacji badacza z badanym. Jest nim „projekcja na badacza”. Odzwierciedla ona reakcje badanego będące jakby „odpowiedzią” na najczęściej niezwerbalizowane oczekiwania badacza. Badany jakby chciał sprostać, w jego mniemaniu, wymogom badania, udzielić odpowiedzi, których jego zdaniem oczekuje badacz. Badany stara się, by badanie dobrze wypadło i by badacz był zadowolony z jego przebiegu i treści narracji. Warto zwrócić uwagę, o czym pisze Borowska-Beszta, że kompetencje badacza mogą implikować narrację badanego i określony sposób konstruowania biografii oraz jej relacjonowania (Borowska-Beszta 2011a: 119). W tym kontekście trzeba podkreślić, jak ważna jest autokontrola badacza, jak ważnym jest rozpoznawanie wiedzy o sobie jako badaczu, by zapobiec ewentualnym zniekształceniom w procesie badania biograficznego.

Sytuacja badania biografii niewątpliwie, i to $\mathrm{z}$ wielu perspektyw, jest równocześnie uczeniem się badacza. Biografia badanego często odsyła badacza do własnych doświadczeń, poszerza je i rewiduje. Badanie biografii Innych, pozyskana tą drogą wiedza i emocjonalne przeżycia często nie dają się wziąć w nawias. Badacz nie tylko je analizuje i interpretuje, ale także, mniej lub bardziej świadomie, włącza je we własną biografie. W podobnym duchu pisze o tym Luba Jakubowska: „Każde przeprowadzone badanie jest elementem biografii badacza, zatem również może być ważnym obszarem uczenia się (dla badacza)" (Jakubowska 2011a: 194). Trzeba też przyjąć, że sytuacja badania biografii staje się elementem biografii tak narratora, jak i badacza. W przypadku badacza nie jest to tylko poszerzanie biografii naukowej, w tym doświadczeń metodologiczno-warsztatowych, ale także poszerzanie własnej biografii ogólnej - całościowej.

Trzeba też uwypuklić, że sytuacja badania biografii, z perspektywy uczenia się z własnej biografii, ma swoją wyraźną dynamikę. Sytuacja wywiadu biograficznego często po raz pierwszy inicjuje świadomą refleksję nad własną biografią. Zaznacza się też rozwój tej refleksyjności już w trakcie wywiadu oraz jej, często długą, trwającą nawet wiele lat, kontynuację po zakończonym wywiadzie (Dubas: w druku, t. 5). Jakubowska pisze następująco: „już w tak krótkim wycinku rzeczywistości, jakim jest trwanie wywiadu, osoba badana «uczy się refleksji» nad własną biografią”, co uwypukla już np. prosty zabieg definiowania określenia „biografii” na początku i na końcu wywiadu (Jakubowska 2011a: 194). Borowska-Beszta stwierdza natomiast, że „Dochodzenie do kwestii uczenia się było zatem stopniowym procesem interakcyjnym (...) Nie ujawniało się od początku rozmowy, lecz było stopniowo dekodowane przez autorefleksję Narratora. (...) Wiązało się z przypo- 
minaniem, werbalizowaniem uprzednio zreflektowanych faktów i zjawisk z własnej biografii i życia" (Borowska-Beszta 2011a: 119). Sytuacja wywiadu biograficznego jawi się więc nie tylko jako doświadczenie badawcze, ale także jako ważne doświadczenie egzystencjalne, skłaniające poprzez autorefleksję do zmiany perspektywy spostrzegania siebie i otaczającego świata, co niewątpliwie można określić jako wynik procesu uczenia się.

Prowadzenie wywiadu sprzyjającego badaniu/poznawaniu biografii wymaga przygotowania badacza, ale także i narratora. Jest mu bowiem potrzebny czas na namysł nad własną biografią w kontekście tematyki wywiadu. Wywiad zapowiedziany sprzyja przemyśleniu biografii już przed rozmową z badaczem. W trakcie rozmowy możliwy jest dalszy, i już bardziej pogłębiony, namysł nad biografią przemyślaną wcześniej. Oczywiście, badacza mogą też interesować wypowiedzi udzielane spontanicznie czy odpowiedzi projekcyjne. Jednak, gdy chodzi o uruchomienie i rozwój procesu uczenia się z własnej biografii, ważne jest przygotowanie i czas. Uczenie się bowiem zazwyczaj wymaga przygotowania i czasu. Tezy do wywiadu, jakie badacz może udostępnić narratorowi przed wywiadem, mogą działać jak zachęta do refleksji nad życiem. Autoryzacja transkrypcji wywiadu i walidacja komunikacyjna mogą być kolejnym ważnym krokiem w kontynuacji refleksji nad życiem i biografią (Dubas 2011a, 1: 207).

\section{Metodyczne wskazania dla edukacji dorosłych wynikające z badania procesu uczenia się z własnej biografii}

Badania biografii w aspekcie uczenia się z własnej biografii potwierdzają przydatność nowoczesnych form edukacji dorosłych w procesie pracy edukacyjnej z dorosłymi. Nowoczesna kultura edukacji dorosłych a nie tradycyjna (Solarczyk-Szwec, Matlakiewicz 2005: 61-68), model dydaktyki humanistycznej i krytycznej a nie model technologiczny w edukacji dorosłych (por. Malewski 2010: 22-43), model procesualny andragogiczny a nie pedagogiczny treściowy (Knowles, Holton III, Swanson 2009) stanowią dobry metodyczny wybór, gdy chodzi o indywidualizowanie procesu uczenia się, autonomię - podmiotowość i zaangażowanie dorosłego uczącego się w ten proces oraz efekty tego uczenia się, które widoczne są w przemianach jego tożsamości i lepszym radzeniu sobie $\mathrm{z}$ trudnościami życiowymi i samorealizacją. Badanie biografii - rozpoznawanie życiowych doświadczeń i refleksja nad nimi - stanowi zasadę zajęć z dorosłymi nazywanymi przez Olgę Czerniawską dydaktyką biograficzną (por. Czerniawska 2000, 2007, 2011a). Częstą formą tych zajęć są grupowe warsztaty biograficzne (por. Wawrzyniak, Wypiorczyk-Przygoda 2011b: 209-232). Bazowanie na doświadczeniu biograficznym dorosłych, postulowane w andragogice od dawna (por. Lindeman 1926, za: Knowles, Holton III, Swanson 2009: 46), można uznać za swoisty aksjomat edukacji dorosłych. Jedno z pięciu kluczowych założeń teorii uczenia się dorosłych, sformu- 
łowanych przez Lindemana brzmi: „Doświadczenie jest najbogatszym źródłem uczenia się dorosłych, dlatego też centralnym punktem metodyki edukacji dorosłych jest analiza doświadczenia” (Knowles, Holton III, Swanson 2009: 46). Wyraźnie potwierdza to badanie zrealizowane przez Annę Frąckowiak, gdy pisze: „Można zaryzykować stwierdzenie, że w przypadku osób dorosłych doświadczenia życiowe, zarówno o charakterze osobistym, zawodowym, jak i edukacyjnym, są niejednokrotnie większym i istotniejszym źródłem procesu uczenia się, jak też i jego inspiracją, niż edukacja zorganizowana, opierająca się na wiedzy książkowej. Dla perspektywy andragogicznej oznacza to przede wszystkim zmianę proporcji pomiędzy przekazywaniem gotowej wiedzy a odwoływaniem się do przeżyć i przemyśleń osób dorosłych podejmujących edukację" (Frąckowiak 2011a: 227). Trzeba podkreślić, że w rzeczywistość zinstytucjonalizowanej formalnej i pozaformalnej edukacji dorosłych włącza się nieformalny proces uczenia się dorosłych. Te trzy tryby uczenia się łączą się ze sobą, zazębiają się. Frąckowiak pisze: „Studiowanie, zdobywanie wiedzy w sposób formalny, jak też i uczenie się z biografii to procesy, które wzajemnie się przenikają" (tamże: 228). Często jest też tak, że dla dorosłego uczenie się z własnej poznawanej i reflektowanej biografii bywa bardziej znaczące dla dalszego życia niż uczenie się formalne. Frąckowiak stwierdza: „W przypadku Narratorki o wiele bardziej istotne jest uczenie się z samego życia oraz własnej biografii niż uczenie się formalne" (por. tamże: 226).

\section{Uczenie się z własnej biografii w odniesieniu do biograficznego uczenia się}

Uczenie się z własnej biografii można uznać za przykład biograficznego uczenia się (Alheit 2011; Bron 2009). Biografia w tym kontekście jest traktowana jako obszar uczenia się. Narracja autobiograficzna (mówiona, pisana, myślana), analiza własnej biografii i jej wielokrotne interpretacje sprzyjają pozyskiwaniu wiedzy o sobie, o innych i o rzeczywistości, której doświadcza/ł narrator. W procesie uczenia się z własnej biografii uczący się dorosły uzyskuje wiedzę i umiejętności na drodze refleksyjnego poznania i refleksyjnej kontemplacji ${ }^{3}$ własnej biografii. Na swój zindywidualizowany i niepowtarzalny sposób, jako podmiot uczący się (z) siebie samego, „wydobywa” wiedzę do tej pory mu nieznaną, nieuświadomioną, do tej pory utajoną. Wiedza ta $\mathrm{w}$ istotny sposób wspiera proces jego dalszego rozwoju, poprzez poznanie i zrozumienie tego, co do tej pory było niejasne, budziło wątpliwości i niepokoiło. Pozwala na redefinicje i modyfikacje własnej tożsamości, która dotychczas mogła funkcjonować w napięciu konfliktogennym, zaburzając poczucie sensu życia i harmonię wewnętrzną. Uczenie się z własnej biografii może sprzyjać

\footnotetext{
${ }^{3}$ Por. teoria egzystencjalnego uczenia się Petera Jarvisa, trajektorie owocne nr 6 i 8 (za: Malewski 2010: s. 13-104).
} 
też „radykalnej zmianie rozwojowej poznającego podmiotu”, a tym samym być przykładem transformatywnego uczenia się (Mezirow, za: Malewski 1998: 112-113).

Ważnym osiągnięciem zrealizowanych badań nad biograficznym uczeniem się, w tym w szczególności badań nad uczeniem się z własnej biografii, jest wydobycie właśnie edukacyjnego wymiaru badania/poznawania (auto)biografii; badanie biografii uczy, poucza, skłania do uczenia się tak badacza, jak i badanego. To wielowariantowe uczenie się można dostrzec w następujących funkcjach badania (auto)biografii:

- funkcji reminiscencyjnej, polegającej na przypominaniu, by pamiętać, wydobywaniu $\mathrm{z}$ rezerwuarów niepamięci, utrwalaniu $\mathrm{w}$ pamięci, ćwiczeniu pamięci;

- funkcji historyczno-kulturowej, rozumianej jako pozyskiwanie wiedzy o historii, kulturze i społeczeństwie, zawartej w jednostkowych biografiach, jako pozyskiwanie informacji o tym, jak było dawniej;

- funkcji genetycznej, która sprzyja odnajdowaniu przyczyn określonych zachowań, postaw i wyborów jednostki oraz osób z jej otoczenia, odnajdowaniu uwarunkowań pamiętanych wydarzeń i zjawisk;

- funkcji temporalnej, oznaczającej rozpoznawanie, „scalanie” i harmonizowanie perspektyw czasowych doświadczania życia przez jednostkę (retrospektywnej - opisującej przeszłość, prezentystycznej - opisującej teraźniejszość, futurystycznej - szkicującej przyszłość, transcendentalnej - odnoszącej się do wieczności) w reflektowanej i ponownie konstruowanej biografii;

- funkcji międzypokoleniowej przejawiającej się w międzypokoleniowym przekazie wartości kulturowych i wiedzy, w poszerzaniu wiedzy o innych pokoleniach, zbliżaniu pokoleń;

- funkcji autoformacyjnej, gdy praca z biografią jest czynnikiem formacji osoby, sprzyja samopoznaniu, autokreacji, autotransformacji w wyniku namysłu nad biografią;

- funkcji formacyjnej - kształcącej i wychowawczej, przejawiającej się w kształcącym i wychowawczym oddziaływaniu biografii badanego na biografię badacza czy innych jej odbiorców, w kierowaniu procesem badania biograficznego uczącego się z biografii, np. poprzez wywiad biograficzny czy podczas zajęć z zakresu dydaktyki biograficznej (por. też Dubas 2014a; Dubas 2011b);

- funkcji sensotwórczej, która uwypukla odnajdowanie i utrwalanie poczucia sensu doświadczanego życia, powiązanego z rekonstrukcjami i modyfikacjami tożsamości.

Biograficzne uczenie się, w tym także uczenie się z własnej biografii, opiera się na biograficzności rozumianej jako osobowa kompetencja (Dubas 2015). Biograficzność oznacza mechanizm osobowej autoformacji przejawiający się jako umiejętność uczenia się sprzyjającego redefinicjom i modyfikacjom własnej tożsamości, poprzez poszukiwanie możliwości jej zmian tkwiących we własnej biografii 
(wewnątrz systemu), w oparciu o proces pogłębionej autorefleksji, jak również refleksji kierowanej zewnętrznie (z zewnątrz systemu), np. przez mentora, edukatora podczas zajęć biograficznych czy podczas wywiadu biograficznego, nad doświadczeniami życiowymi wydobywanymi poprzez narrację z pamięci autobiograficznej (por. tamże: 26). Biograficzność jako osobowa kompetencja sprzyja biograficznemu uczeniu się, a nawet jest koniecznością dla jego zaistnienia.

Biograficzne uczenie się to specyficzny proces uczenia się, realizowany przez człowieka podejmującego namysł nad biografią oraz poznającego i zmieniającego siebie oraz swój świat życia w wyniku tej refleksji. Bazuje ono na doświadczeniach życiowych jednostki, ma wymiar emocjonalny, poznawczy i społeczny, a także aksjologiczny i egzystencjalny. Jest celowe i sprzyja modernizacji tożsamości. Ma wymiar praktyczny w tym sensie, że przyczynia się do efektywniejszego funkcjonowania w zmieniającym się i trudnym świecie. Najczęściej nie bywa uświadomione, lecz można je uświadamiać i wyzwalać. Może być zakotwiczone we wszystkich wymiarach czasu. Jest sytuacyjne i ma charakter społeczny i kulturowy. Silnie opiera się o struktury społeczne (w tym instytucje edukacyjne, poczynając od nauki szkolnej w dzieciństwie), które nadały określone formy i schematy uczeniu się jednostki. Biograficzne uczenie się silnie zależy od doświadczeń edukacyjnych człowieka; im edukacja bardziej podmiotowa i wyzwalająca, ukierunkowana na samodzielne rozwiązywanie problemów i na autokreację uczącego się, na twórczość i zmianę, na realizowanie zadań społecznych i zarazem na samorealizację jednostki, tym procesy biograficznego uczenia się są bardziej widoczne. Biograficzne uczenie się to proces charakterystyczny głównie dla dorosłości, choć jego początki mogą mieć miejsce i we wcześniejszych okresach życia (por. Pietrasiński 1990: 166-169). Biograficzne uczenie się może być inicjowane, stymulowane i rozwijane. Umiejętność biograficznego uczenia się można ćwiczyć, co potwierdzają wyniki badań nad uczeniem się z własnej biografii.

\section{Podsumowanie}

Na podstawie wyników zrealizowanego projektu można stwierdzić, że uczenie się z własnej biografii, mimo podejmowanej przez narratorów refleksji nad własnymi doświadczeniami życiowymi oraz mimo udanych prób konstrukcji własnej biografii, jest procesem prawie nieobecnym, nieuświadomionym i niepraktykowanym. Badani nie doświadczyli wcześniej stymulacji do uczenia się z własnej biografii, jak również nie posiadali umiejętności takiego uczenia się. Uczenie się z własnej biografii, zainicjowane często dopiero przez wywiad, okazało się być jednak bardzo przydatnym, np. dla rozwiązywania trudnych problemów egzystencjalnych; ujawniało się wtedy jako obszar egzystencjalnego uczenia się. Trzeba jednak podkreślić, że stosunkowo łatwo rozbudzić świadomość i potrzebę uczenia się z własnej 
biografii, choćby już w trakcie trwania wywiadu biograficznego. Tak zainicjowane uczenie się wzbudzało emocje i zajmowało badanego jeszcze przez dłuższy czas. Podjęcie uczenia się z własnej biografii charakteryzowało osoby lepiej wykształcone (Dubas 2015: 36), które potrafiły werbalizować swe myśli i nazywać emocje, odnosić się do swych doświadczeń życiowych krytycznie, otwierać się na nowe perspektywy spostrzegania siebie i świata i poszukiwać nowych znaczeń.

Uczenie się z własnej biografii, będące przykładem biograficznego uczenia się, należy rozumieć więc jako badanie, poznawanie, ponowne doświadczanie własnej biografii w wyniku narracji, refleksji i interpretacji własnych doświadczeń biograficznych. Efektem tego procesu jest odkrywanie nowej wiedzy: o sobie, o innych, o świecie i wszechświecie, która sprzyja rekonstrukcjom, redefinicjom i modyfikacjom własnej tożsamości. W wyniku tego procesu jednostka odzyskuje sens swojego życia i poczucie życiowego sprawstwa. Uczenie się z własnej biografii może odbywać się tak w sytuacji wywiadu biograficznego, indywidualnego lub grupowego, jak i biograficznych zajęć edukacyjnych i terapeutycznych czy też podczas indywidualnie prowadzonej refleksji autobiograficznej (np. poprzez pisanie pamiętnika, rozmyślanie nad swym życiem, bilansowanie życia). Uczenie się z własnej biografii jest procesem wymagającym inspiracji i ukierunkowania z zewnątrz. Oznacza też długotrwały dynamiczny proces uczenia się włączonego w codzienność, warunkowanego strukturą społeczną, choć wykraczającego poza nią jako przykład aktywności świadomego, otwartego na zmiany i twórczego podmiotu. Umiejętność uczenia się z własnej biografii to niezwykle wartościowe, jak dotychczas jednak niedoceniane, „narzędzie” wspierające proces rozwoju człowieka (dorosłego).

\section{Bibliografia}

Alheit P. (1990) Biographizitat als Projekt Der „biographische Ansatz“ in der Erwachsenenbildung, Bremen.

Alheit P. (2011) Podejście biograficzne do całożyciowego uczenia się, „Człowiek - Teraźniejszość - Edukacja", nr 3 (55), s. 7-21.

Bardziejewska M. (2005) Okres dorastania. Jak rozpoznać potencjał nastolatków? w: Psychologiczne portrety człowieka Praktyczna psychologia rozwojowa, A. I. Brzezińska (red.), Gdańsk, GWP, s. 345-377.

Borowska-Beszta B. (2011a) „Sama sobie tak postanowiłam, bo miałam dosyć takiego życia...[...] Uczenie się z własnej biografii w badaniach andragogicznych w: Uczenie się $z$ (własnej) biografii, E. Dubas, W. Świtalski (red.) seria: Biografia i badanie biografii, t. 1, Łódź, Wydawnictwo Uniwersytetu Łódzkiego, s. 105-131. 
Bron A. (2009) Biograficzność w badaniach andragogicznych, „Dyskursy Młodych Andragogów", nr 10, s. 39-53.

Czerniawska 0. (2000) Drogi i bezdroża andragogiki i gerontologii, Łódź, Wydawnictwo Wyższej Szkoły Humanistyczno-Ekonomicznej w Łodzi.

Czerniawska O. (2007) Szkice z andragogiki i gerontologii, Łódź, Wydawnictwo Wyższej Szkoły Humanistyczno-Ekonomicznej w Łodzi.

Czerniawska 0. (red.) (2011a) Andragogiczny wymiar wydarzeń osobistych i globalnych $w$ badaniach biograficznych, Łódź, Wydawnictwo Akademii Humanistyczno-Ekonomicznej w Łodzi.

Czerniawska O. (2011b) Nowe drogi w andragogice i gerontologii, Łódź, Wydawnictwo Akademii Humanistyczno-Ekonomicznej w Łodzi.

Dominice P. (2006) Uczyć się z życia. Biografia edukacyjna w edukacji dorosłych, Łódź, Wydawnictwo Wyższej Szkoły Humanistyczno-Ekonomicznej w Łodzi.

Dubas E. (2009) Refleksja autobiograficzna jako aktywność edukacyjna w kontekście całożyciowego uczenia się w: Aktywność społeczna, kulturalna i oświatowa dorosłych, A. Fabiś, S. Kędziora (red.), Mysłowice-Zakopane, Górnośląska Wyższa Szkoła Pedagogiczna w Mysłowicach, s. 41-53.

Dubas E. (2011a, 1) „Ja mam parę żyć - uczenie się z własnej biografii (w świetle analizy jednego wywiadu) w: Uczenie się z (własnej) biografii, E. Dubas, W. Świtalski (red.), seria: Biografia i badanie biografii, t. 1, Wydawnictwo Uniwersytetu Łódzkiego, Łódź, s. 197-213.

Dubas E. (2011a, 2) Uczenie się z (własnej) biografii - wprowadzenie w: Uczenie się $z$ (własnej) biografii, E. Dubas, W. Świtalski (red.), seria: Biografia i badanie biografii, t. 1, Łódź, Wydawnictwo Uniwersytetu Łódzkiego, s. 5-9.

Dubas E. (2011b) Życie zdeterminowane historiq. Uczenie się z biografii Innego. Na przykładzie relacji Renee Villancher „Moje skradzione życie” w: Uczenie się z biografii Innych, E. Dubas, W. Świtalski (red.), seria: Biografia i badanie biografii, t. 2, Łódź, Wydawnictwo Uniwersytetu Łódzkiego, s. 77-92.

Dubas E. (2014a) Edukacja w andragogicznych badaniach biograficznych - biografia edukacyjna w: Badanie biografii - źródła, metody, konteksty, R. Skrzyniarz, E. Krzewska, W. Zgłobicka-Gierut (red.), Lublin, Wydawnictwo Episteme, s. 17-31.

Dubas E. (2014b) „Ja przez całe życie nie przeczytałem ksiq̨żki...” Nietypowa biografia edukacyjna - uczenie się „poza” książkq w: Biografia i badanie biografii. Biografie edu- 
kacyjne. Wybrane konteksty, E. Dubas, J. Stelmaszczyk (red.), seria: Biografia i badanie biografii, t. 3, Łódź, Wydawnictwo Uniwersytetu Łódzkiego, s. 11-31.

Dubas E. (2015a) Andragogiczne badania biografii - zakresy, trudności, etyka badacza (wybrane aspekty) w: Biografie i uczenie się, E. Dubas, J. Stelmaszczyk (red.), seria: Biografia i badanie biografii, t. 4, Łódź, Wydawnictwo Uniwersytetu Łódzkiego, s. 31-47.

Dubas E. (2015b) Biograficzność w kontekście całożyciowego uczenia się w: Biografie i uczenie się, E. Dubas, J. Stelmaszczyk (red.), seria: Biografia i badanie biografii, t. 4, Łódź, Wydawnictwo Uniwersytetu Łódzkiego, s. 11-29.

Dubas E. (w druku) Czas w andragogicznym podejściu biograficznym - wybrane konteksty w: Czas i miejsca w biografii. Aspekty edukacyjne, E. Dubas, A. Gutowska (red.), seria: Biografia i badanie biografii, t. 5, Łódź, Wydawnictwo Uniwersytetu Łódzkiego.

Dubas E., Gutowska A. (red.) (w druku) Czas i miejsca w biografii. Aspekty edukacyjne, seria: Biografia i badanie biografii, t. 5, Łódź, Wydawnictwo Uniwersytetu Łódzkiego.

Dubas E., Stelmaszczyk J. (red.) (2014) Biografie edukacyjne. Wybrane konteksty, seria: Biografia i badanie biografii, t. 3, Łódź, Wydawnictwo Uniwersytetu Łódzkiego.

Dubas E., Stelmaszczyk J. (red.) (2015) Biografie i uczenie się, seria: Biografia i badanie biografii, t. 4, Łódź, Wydawnictwo Uniwersytetu Łódzkiego.

Dubas E., Świtalski W. (red.) (2011a) Uczenie się z (własnej) biografii, seria: Biografia i badanie biografii, t. 1, Łódź, Wydawnictwo Uniwersytetu Łódzkiego.

Dubas E., Świtalski W. (red.) (2011b) Biografia i badanie biografii. Uczenie się z biografii Innych, seria Biografia i badanie biografii, t. 2, Łódź, Wydawnictwo Uniwersytetu Łódzkiego.

Frąckowiak A. (2011a) Studiować czy uczyć się z biografii? w: Uczenie się z (własnej) biografii, E. Dubas, W. Świtalski (red.), seria: Biografia i badanie biografii, t. 1, Łódź, Wydawnictwo Uniwersytetu Łódzkiego, s. 215-229.

Gajek K. (2011a) Biograficzna praca nad trajektoria jako sposób zdefiniowania tożsamości w: Uczenie się z (własnej) biografii, E. Dubas, W. Świtalski (red.), seria: Biografia i badanie biografii, t. 1, Łódź, Wydawnictwo Uniwersytetu Łódzkiego, s. 43-50.

Golonka J. (2011a) „Uczenie się z biografii” - indywidualna koncepcja wykorzystania wywiadu biograficznego w: Uczenie się z (własnej) biografii, E. Dubas, W. Świtalski (red.), seria: Biografia i badanie biografii, t. 1, Łódź, Wydawnictwo Uniwersytetu Łódzkiego, s. 163-183. 
Illeris K. (2006) Trzy wymiary uczenia się, Wydawnictwo Naukowe Dolnośląskiej Szkoły Wyższej TWP we Wrocławiu, Wrocław.

Jakubowska L. (2011a) Uczenie się z biografii. Badania auto/biograficzno-narracyjne w: Uczenie się z (własnej) biografii, E. Dubas, W. Świtalski (red.), seria: Biografia i badanie biografii, t. 1, Łódź, Wydawnictwo Uniwersytetu Łódzkiego, s. 185-195.

Kafar M. (2011) Biograficzne epifanie w kontekście tworzenia podstaw jakościowego kolektywu myślowego w: Biografie naukowe Perspektywa transdyscyplinarna, M. Kafar (red.), Łódź, Wydawnictwo Uniwersytetu Łódzkiego, s. 37-66.

Knowles M. S., Holton III E. F., Swanson R. (2009) Edukacja dorosłych. Podręcznik akademicki, Warszawa, Wydawnictwo Naukowe PWN.

Kostrzyńska M. (2011b) Ścieżki dochodzenia do bezdomności. Rekonstrukcja procesu na przykładzie badań biografii bezdomnych w: Uczenie się z biografii Innych, E. Dubas W. Świtalski (red.), seria: Biografia i badanie biografii, t. 2, Łódź, Wydawnictwo Uniwersytetu Łódzkiego, s. 157-173.

Krawczyk-Bocian A. (2011a) Zdarzenia krytyczne $w$ biografii indywidualnej młodych dorosłych w: Uczenie się z (własnej) biografii, E. Dubas, W. Świtalski (red.), seria: Biografia i badanie biografii, t. 1, Łódź, Wydawnictwo Uniwersytetu Łódzkiego, s. 69-90.

Krysztofik J., Walulik A. (w druku) Temporalny charakter synergii edukacyjnych w: Czas i miejsca w biografii. Aspekty edukacyjne, E. Dubas, A. Gutowska (red.), seria: Biografia i badanie biografii, t. 5, Łódź, Wydawnictwo Uniwersytetu Łódzkiego.

Lalak D. (2010) Życie jako biografia. Podejście biograficzne w perspektywie pedagogicznej, Warszawa, Wydawnictwo Akademickie ŻAK.

Lasocińska K. (2014) Autobiografia jako autokreacja. Twórcze aspekty procesu myślenia autobiograficznego w edukacji dorosłych w: Biografie edukacyjne. Wybrane konteksty, E. Dubas, J. Stelmaszczyk (red.), seria: Biografia i badanie biografii, t. 3, Łódź, Wydawnictwo Uniwersytetu Łódzkiego, s. 33-46.

Malewski M. (1998) Teorie andragogiczne. Metodologia teoretyczności dyscypliny naukowej, Wrocław, Wydawnictwo Uniwersytetu Wrocławskiego.

Malewski M. (2010) Od nauczania do uczenia się. O paradygmatycznej zmianie $w$ andragogice, Wrocław, Wydawnictwo Naukowe Dolnośląskiej Szkoły Wyższej.

Matlakiewicz A., Solarczyk-Szwec H. (2005) Dorośli uczq̨ się inaczej. Andragogiczne podstawy kształcenia ustawicznego, Toruń, Wydawnictwo Centrum Kształcenia Ustawicznego w Toruniu. 
Mazurek E. (2011a) Biograficzne uczenie się kobiety doświadczającej choroby nowotworowej piersi $w$ świetle teorii andragogicznych w: Uczenie się z (własnej) biografii, E. Dubas, W. Świtalski (red.), seria: Biografia i badanie biografii, t. 1, Łódź, Wydawnictwo Uniwersytetu Łódzkiego, s. 51-68.

Mazurek E. (2013) Biografie edukacyjne kobiet dotkniętych rakiem piersi, Wrocław, Oficyna Wydawnicza Politechniki Wrocławskiej.

Pietrasiński Z. (1990) Rozwój człowieka dorosłego, Warszawa, Państwowe Wydawnictwo „Wiedza Powszechna”.

Schlüter A. (2004) Einleitung w: Erfahrung mit Biographien. Tagungsdokumentation der Diusburger Tagungen zum Thema „Erfahrung mit Biographien“, A. Schlüter, I. Schell-Kiehl (red.), Bielefeld, s. 7-20.

Schlüter A., Schell-Kiehl I., (red.) (2004) Erfahrung mit Biographien. Tagungsdokumentation der Diusburger Tagungen zum Thema „Erfahrung mit Biographien“, Bielefeld.

Schütze F. (1983) Biographieforschung und narratives Inerview, „Neue Praxis”, nr 3.

Schütze F. (1997) Trajektorie cierpienia jako przedmiot badań socjologii interpretatywnej, „Studia Socjologiczne”, nr 1, s. 11-56.

Skibińska E. M. (2006) Mikroświaty kobiet. Relacje autobiograficzne, Warszawa, Wydawnictwo Instytutu Technologii Eksploatacji Radom.

Urbaniak-Zając D. (2011a) Biograficzna perspektywa badawcza w: Uczenie się z (własnej) biografii, E. Dubas, W. Świtalski (red.), seria: Biografia i badanie biografii, t. 1, Łódź, Wydawnictwo Uniwersytetu Łódzkiego, s. 11-27.

Wawrzyniak J. K., Wypiorczyk-Przygoda K. (2011b, 1) Pamięć i percepcja początku dorosłości w biografii osób starszych w: Uczenie się z biografii Innych, E. Dubas, W. Świtalski (red.), seria: Biografia i badanie biografii, t. 2, Łódź, Wydawnictwo Uniwersytetu Łódzkiego, s. 217-224.

Wawrzyniak J. K., Wypiorczyk-Przygoda K. (2011b, 2) Warsztaty biograficzne UTW. Rozważania na temat początku drogi życiowej w: Uczenie się z biografii Innych, E. Dubas, W. Świtalski (red.), seria: Biografia i badanie biografii, t. 2, Łódź, Wydawnictwo Uniwersytetu Łódzkiego, s. 209-215.

Wąsiński A. (2011a, 1) Autokreacja w perspektywie narracji i biograficzności w: Uczenie się z (własnej) biografii, E. Dubas, W. Świtalski (red.), seria: Biografia i badanie biografii, t. 1, Łódź, Wydawnictwo Uniwersytetu Łódzkiego, s. 29-42. 
Wąsiński A. (2011a, 2) Proces dojrzewania autokreacyjnego do stworzenia rodziny adopcyjnej na przykładzie wywiadu narracyjnego z francuskim małżeństwem adoptujacym dziecko w Polsce w: Uczenie się z (własnej) biografii, E. Dubas, W. Świtalski (red.), seria: Biografia i badanie biografii, t. 1, Łódź, Wydawnictwo Uniwersytetu Łódzkiego, s. 133-162.

Wnuk-Olenicz M. (2011a) Uczenie się z biografii. Próba analizy jednej biografii w: Uczenie się z (własnej) biografii, E. Dubas, W. Świtalski (red.), seria: Biografia i badanie biografii, t. 1, Łódź, Wydawnictwo Uniwersytetu Łódzkiego, s. 231-239.

Wypiorczyk-Przygoda K., Wawrzyniak J. K. (2011b, 3) Wspomnienie jako obraz przeszłości zachowany w pamięci - skarbnicy przeżyć i doświadczeń w: Uczenie się z biografii Innych, E. Dubas, W. Świtalski (red.), seria: Biografia i badanie biografii, t. 2, Łódź, Wydawnictwo Uniwersytetu Łódzkiego, s. 225-232. 